International Journal of Instruction e-ISSN: 1308-1470 • www.e-iji.net

Article submission code: 20201124071330

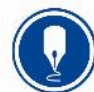

January $2022 \bullet$ Vol.15, No.1

p-ISSN: 1694-609X

pp. $21-38$

Received: 24/11/2020

Revision: 24/05/2021
Accepted: 23/06/2021

OnlineFirst: 04/10/2021

\title{
Attitudes and Cross-cultural Differences of UCSI University Undergraduates towards Multicultural Group Work
}

\section{Lin Siew Eng}

Asst. Prof., corresponding author, Education Department, Faculty of Social Sciences \& Liberal Arts, UCSI University, Malaysia, linsieweng@ gmail.com

\section{Shephanie Kuan Khye Ling}

Faculty of Social Sciences \& Liberal Arts, UCSI Universit, Malaysia, shephaniekkl@gmail.com

Chang Kuan Lim

PhD, ERAS EDUTECH SDN BHD, Malaysia, alexanderckl@hotmail.com

Almost every course in higher education involved some form of multicultural group work activities and these have resulted in numerous problems for undergraduates due to the attitudinal and cultural differences. This study aims to find out the undergraduates' attitudes as well as the effect of cross-cultural differences towards multicultural group work. The mixed method design was used in this study. Questionnaire and interview questions adapted from both Wegelius (2013) and Iskandarova (2016) were used to collect the data. Google form was used for collecting quantitative data. There were 140 respondents comprising both Malaysian respondents and respondents from other nationalities studying in UCSI University. Out of these 140 respondents, eight respondents were selected for indepth interviews. In general, the findings of this study showed that the local and foreign undergraduates' attitudes and language proficiency play major roles towards working effectively in group work. Besides, the data obtained indicated that there are both positive and negative effects of cross-cultural differences towards multicultural group work. A majority of the international undergraduates have a positive outlook when engaging with undergraduates from other countries. However, at times they isolate themselves due to differences in culture, language barriers, cross-cultural communication and attitudes. At the individual level, the findings can be used by students and educators as reference for combating problems encountered during multicultural group work while at the organisation level, the Human Resource Department can plan team building activities to bring the undergraduates together.

Keywords: attitudes, cross-cultural differences, effect, multicultural group work, undergraduates

Citation: Lin, S. E., Kuan, K. L., \& Chang, K. L. (2022). Attitudes and cross-cultural differences of UCSI university undergraduates towards multicultural group work. International Journal of Instruction, 15(1), 21-38. https://doi.org/10.29333/iji.2022.1512a 


\section{INTRODUCTION}

Both the public and private universities in Malaysia face challenges in creating a conducive learning environment for the local and foreign undergraduates. In this globalised world, the classrooms in institutions of higher education are culturally diversified and the demography has drastically shifted (Reid \& Garson, 2016). Educators need to relook at the way the assignments and tasks are developed, prepared, and evaluated for group work. We could begin by emulating from the success of the Swiss education system in harmonizing children from different cultural backgrounds and making use of the various infrastructures and environment of the school. In addition, we could also require teachers to possess some knowledge about the cultures of the students in their classes, (Ari et al., 2021). Besides, this is a great way to build good language skills as working together among the local and foreign undergraduates requires good communication especially in dealing with members of multicultural group. With teamwork gaining importance, numerous problems are very likely to crop up in the multicultural groups as supported by Mittelmeier, et al. (2017), in which they state that cross-cultural group work is often fraught with tension. These problems such as miscommunication to name but one, are mainly due to the differences in the attitude and cultural background among the foreign and local undergraduates. UCSI University located in the capital city of Malaysia is not spared of this issue as well. UCSI University has many foreign students coming from different cultural backgrounds, adding to the diversity of the university. The degree of diversity in a group affects the group dynamics, with the effect of the magnitude of diversity being much stronger (Thomas, 1999; Thomas et al., 2005). However, a too diversified groupwork may cause some problems which influence the synergies especially in working with other ethnic students. In Wright and Lander's (2003) exploration of the differences between having a culturally diverse student population and having students engaged in positive interaction, they unintentionally uncovered the issues of local and foreign students facing a lot of challenges and not working well with each other in group projects. This is in accord with Taras \& Rowney's (2007) view, that cultural diversity can lead to difficulties in teamwork if it is not managed properly. Mittelmeier, et. al., (ibid) also believe that simply assigning group members from different nationalities to a multicultural group does not automatically result in any benefits. More often than not, cross-cultural differences in perceptions of justice may lead to misunderstandings and conflicts (Murphy-Berman \& Berman, 2002).

Two research questions were formulated to provide insights for the study:

1. What are the local and foreign undergraduates' attitudes towards multicultural group work?

2.What are the effects of cross-culture differences among local and foreign undergraduates towards multicultural group work? 


\section{Literature Review}

Group work is an instructional strategy that requires the sharing of knowledge, cooperating with each other to perform a task, and the use of social interaction in order to achieve a high quality of learning (Johnson, et al., 2014). Group work which can encompass group assignments and group projects in all disciplines in higher education is a very common and popular activity which is employed to engage and assess as well as evaluate students' participation and performance in the course that they are pursuing. In carrying out group work, students are not just simply working side by side, helping each other and discussing and sharing materials as well as working to achieve a common goal. Group members must have clear and positive understanding, paying attention to each other and are responsible for their own contributions to the group (Zedda, et al., 2017). However, this form of activity has created its fair share of problems and challenges for the students. In UCSI university, English language is the main medium of instruction and communication. Furthermore, USCI University has a predominantly large Chinese student population with a huge majority of non-native English-speaking foreign students, communication problems may arise from the culturally diverse groups of students' populations aside from their beliefs, attitudes, values and differing perspectives on decision-making, problem solving, conflict management and leadership issues.

Though there have been many researches carried out, these studies mainly highlighted the benefits of multicultural work groups and specifically the need of preparing the students to face the globalised world. However, it must be noted that many students from other cultures are unaccustomed with the responsibilities and duties required of group work. The differing nationalities have different expectations regarding cooperation and commitment between students in group assignment or group project.

\section{Previous Research Done on Multicultural Group Work, Attitudes and Effects of Cross-cultural Differences}

The relationship between the attitudes and the effect of cross-cultural differences is based on the premise that both factors affect multicultural group work. The Similarity Attraction Theory is used to look at the attitudes of undergraduates toward group work. This theory refers to the preference of attracting to people with similarities over dissimilarities. According to Donn Byrne (1971), people are most attracted to others who share similar attitudes in general. This is perhaps by looking for similarities, one may not feel alone in his or her belief by sharing similar attitudes with other human beings.

In this paper, the researcher is also looking at one of Hofstede's (2001) Cultural Dimension. The Individualistic versus Collectivistic Dimension from Hofstede's theory is used to address the question of cross-cultural differences between international and local undergraduates. Individualistic refers to culture with a preference of being alone while collectivistic prefers to be in a group. This is mainly tied to one's culture and traditions preference on being alone or in groups. 


\section{Similarity Attraction Paradigm (Byrne, 1971)}

The Similarity Attraction Paradigm simply states that like-minded people tend to like each other as they possess similarity traits such as values, beliefs, and attitudes. According to Williams and O'Reilly (1998), people who share the same thing are more likely to be attracted to each other and are more willing to cooperate and work together in a group.

A research by Stahl, Maznevski, Voigt \& Jonsen (2010) studied the effects of cultural diversity on teams and multicultural work groups. Their study was also based on the Similarity-Attraction Theory. In another study, Volet and Ang (1998), found out that most students preferred to work with others that have similar cultural backgrounds and were reluctant to mix with people from different cultural backgrounds. In contrast, the findings of Wegelius's (2013) study showed that the participants were willing to work in a multicultural group work.

\section{Hofstede's Cultural Dimensions Theory (2001)}

One of Hofstede's (2001) five cultural dimensions i.e., individualistic versus collectivistic, is used in this study. Often, in individualistic culture, people identify themselves as "I", whereas in collectivistic cultures individuals are seen as part of a group, and they define themselves as "we" (Hofstede \& Hofstede 2005:74-75). One's culture can be a major factor that can influence how people think and their preferences or opinions about the things they do. Countries like Germany, the United States and Australia are individualistic. They are more individual-oriented and stress personal achievements and individual rights. These people tend to be more independent and selfreliant. Consequently, they tend to feel more at ease and comfortable working alone. On the other hand, Eastern countries like Malaysia, China, Japan, and South Korea have higher collectivistic traits as they focus more on working in group such as maintaining harmony in the group, favouritism towards group members and emphasis on the hierarchy of the group.

Besides, Ochieng \& Price (2010) tailored a qualitative research design with interviews focusing on 20 senior project managers. The results indicated that collectivism is more effective than individualism when it comes to group projects, particularly in construction management. Bochner and Hesketh's (2014) study on "Power Distance, Individualism/Collectivism, and Job-Related Attitudes in a Culturally Diverse Work Group" touches on Hofstede's Cultural Dimensions (2001) on power distance and, individualism versus collectivism in group work. Besides, Wegelius's (2013) study is also related to this research as it touches on multicultural group work while using Hofstede's cultural dimensions.

\section{Attitudes towards Working in Multicultural Environment}

Matveev and Nelson's (2004) study on "Cross Cultural Communication Competence and Multicultural Team Performance", also described how people from different cultural backgrounds perceive team members who are competent. This research is 
aligned to a study by Brown (2009) on cross-cultural communication which highlighted the attitude and communication of people from different cultures in a multicultural environment. This research is also further supported by another similar study by Saaristo (2012), who carried out a research on knowledge management and sharing, in multicultural companies using interviews and observations. The research looked at the attitudes of the participants in a multicultural environment.

\section{Effects of Cross-Cultural Differences on Team Performance}

The effects of cross-cultural differences on team performance within an educational setting was explored by Iskandarova (2016). It was found that team performance could be drastically improved by eliminating the cultural constraints and decreasing the cultural challenges.

\section{METHOD}

The mixed method was used to carry out this study. The research participants were undergraduates from four different faculties from the Kuala Lumpur Campus of UCSI University namely: Faculty of Social Sciences and Liberal Arts (FOSSLA), Faculty of Applied Science (FAS), Faculty of Business and Information Science (FOBIS) and Faculty of Engineering and Technology Build Environment (FETBE). The data was collected through interviews and questionnaires and analysed using SPSS. The questionnaires for the survey on the attitude of the participants towards multicultural group work were adapted from Wegelius's (2013) research while the interview questions which explored the effect of cross-cultural differences on team performance within an educational setting were adapted from Iskandarova's (2016) research. A thematic approach was designed for the interview questions since they comprised of questions that were related to the theme of this research which are multicultural group work, attitude, and cross-cultural differences. In addition, studies by Saaristo (2012), Shackleton and Abbas (1990), Bochner and Hesketh (1994) also used questionnaire as their research tool which were all based on Hofstede's model using a seven-point scale.

Firstly, 140 participants comprising of both local and foreign undergraduates from four different faculties at UCSI University were selected to answer the questionnaire online. The 140 questionnaires were collected using Google forms as it is easy for stratified sampling purposes and are easily accessible to the participants.

Secondly, interviews were conducted using purposive sampling (Creswell, 2012) for eight selected participants. A recording application from a smartphone was also used to get the in-depth data from the participants.

Thirdly, the qualitative data from the interview was analysed by using thematic content analysis and the themes were developed using the codings from the interview transcripts. Meanwhile, the questionnaire data was analysed statistically using the Statistical Package for the Social Sciences (SPSS). 


\section{FINDINGS}

Research Question 1: What are the local and foreign undergraduates' attitudes towards multicultural group work?

Table 1

Students' perceptions towards multicultural group work

\begin{tabular}{lllll}
\hline Nationality & $\begin{array}{l}\text { I love doing group wor I am fine doing group } \\
\text { in a multicultural grou }\end{array}$ & $\begin{array}{l}\text { I dislike doing group } \\
\text { work in a } \\
\text { multicultural group }\end{array}$ & $\begin{array}{l}\text { I would rather work } \\
\text { multicultural group }\end{array}$ & $\begin{array}{l}\text { group a single-culture } \\
\text { group }\end{array}$ \\
\hline Malaysia & $14.5 \%$ & $65.8 \%$ & $5.2 \%$ & $14.5 \%$ \\
\hline Others & $13.8 \%$ & $79.3 \%$ & $0.0 \%$ & $6.9 \%$ \\
\hline
\end{tabular}

Generally, Table 1 shows that both local and other nationalities agree that they are 'fine' doing group work in a multicultural group. Only $5.2 \%$ of the local respondents 'dislike doing group work in a multicultural group' as compared to none of the respondents from the other nationalities. It also reveals that a higher percentage of the local respondents compared to that of the other nationalities 'would rather work in a single-culture group'.

Table 2

Types of group that respondents rather work in

\begin{tabular}{llllll}
\hline Nationality & $\begin{array}{l}\text { A single- } \\
\text { cultural } \\
\text { group }\end{array}$ & $\begin{array}{l}\text { A group where } \\
\text { there is an } \\
\text { equal number } \\
\text { of people from } \\
2 \text { cultures }\end{array}$ & $\begin{array}{l}\text { A group where most } \\
\text { of the people are from } \\
\text { the same culture, but } \\
\text { one or two are form } \\
\text { other cultures }\end{array}$ & $\begin{array}{l}\text { A group where } \\
\text { there are several } \\
\text { representatives of } \\
\text { several cultures }\end{array}$ & $\begin{array}{l}\text { A group where } \\
\text { everyone is } \\
\text { from a } \\
\text { different } \\
\text { culture }\end{array}$ \\
\hline $\begin{array}{l}\text { Malaysia } \\
\text { Others }\end{array}$ & $\begin{array}{l}17.4 \% \\
10.4 \%\end{array}$ & $35.0 \%$ & $20.1 \%$ & $7.0 \%$ \\
\hline
\end{tabular}

The group where there are several representatives of several cultures obtained the highest percentage at $37.9 \%$ (respondents from the other nationalities) against $20.1 \%$ (local respondents). Meanwhile $35 \%$ of the Malaysian respondents and $41.4 \%$ of the respondents from the other nationalities preferred 'a group where most of the people are from the same culture, but with one or two are form other cultures. This indicates that both groups of respondents are more comfortable being the majority in the group as opposed to being the minority. Surprisingly, $20 \%$ of the local respondents prefer to work in 'a single-cultural group' while none of the respondents from the other nationalities want to work in 'a single-cultural group'. Overall, the respondents from the other nationalities seemed more open to the idea of working in a multicultural group.

Table 3

Factors that make multicultural group work challenging

\begin{tabular}{lllllll}
\hline Nationality & $\begin{array}{l}\text { Cross-cultural } \\
\text { communication } \\
\text { challenges }\end{array}$ & $\begin{array}{l}\text { ncreased } \\
\text { tmbiguity }\end{array}$ & $\begin{array}{l}\text { More conflict: } \\
\text { harder to reach } \\
\text { agreement }\end{array}$ & $\begin{array}{l}\text { Complicated } \\
\text { things }\end{array}$ & $\begin{array}{l}\text { Other } \\
\text { reasons }\end{array}$ & $\begin{array}{c}\text { All } \\
\text { of the } \\
\text { above }\end{array}$ \\
\hline Malaysia & $33.3 \%$ & $11.1 \%$ & $23.1 \%$ & $17.9 \%$ & $5.1 \%$ & $9.4 \%$ \\
\hline Others & $37.9 \%$ & $10.3 \%$ & $10.3 \%$ & $6.9 \%$ & $0 \%$ & $34.5 \%$ \\
\hline
\end{tabular}


Table 3 shows both group of respondents agree that the factor of 'cross-cultural communication challenges' is the main factor that resulted in 'working in a multicultural group work a challenge'. However, $34.5 \%$ of the respondents from the other nationalities found that all the above factors make multicultural group work challenging.

Table 4

Types of communication problems encountered in multicultural group work

\begin{tabular}{llllll}
\hline Nationality & $\begin{array}{l}\text { Different levels } \\
\text { of literacy }\end{array}$ & $\begin{array}{l}\text { Different manners of } \\
\text { speaking }\end{array}$ & $\begin{array}{l}\text { Differences in } \\
\text { usage of silence }\end{array}$ & $\begin{array}{l}\text { Other } \\
\text { reasons }\end{array}$ & $\begin{array}{l}\text { All of the } \\
\text { above }\end{array}$ \\
\hline Malaysia & $32.5 \%$ & $39.3 \%$ & $10.3 \%$ & $3.4 \%$ & $14.5 \%$ \\
Others & $20.7 \%$ & $55.2 \%$ & $0.0 \%$ & $0.0 \%$ & $24.1 \%$ \\
\hline
\end{tabular}

There are basically three main communication problems arising from multicultural group work. Generally, both the Malaysian respondents $(39.3 \%)$ and respondents from the other nationalities (55.2\%) agree that 'different manners of speaking' is the main problem. The second main problem is the different levels of literacy while for the third problem, none of the respondents from the other nationalities $(0 \%)$ chose 'differences in the usage of silence' though silence do convey different meanings to different people. In addition, $24.1 \%$ of the respondents from other nationalities feel that the communication problems encountered are due to all the three reasons stated.

Table 5

Types of strategies used to overcome the communication problems

\begin{tabular}{lllllllll}
\hline $\begin{array}{l}\text { Nationa- } \\
\text { lity }\end{array}$ & $\begin{array}{l}\text { Speaking } \\
\text { more } \\
\text { clearly }\end{array}$ & $\begin{array}{l}\text { Asking } \\
\text { for } \\
\text { clarific- } \\
\text { ation }\end{array}$ & $\begin{array}{l}\text { Checking } \\
\text { for } \\
\text { understan- } \\
\text { ding }\end{array}$ & $\begin{array}{l}\text { Favouring } \\
\text { face-to- } \\
\text { face } \\
\text { meetings }\end{array}$ & $\begin{array}{l}\text { Use of } \\
\text { Whats- } \\
\text { app }\end{array}$ & $\begin{array}{l}\text { Being } \\
\text { Patient }\end{array}$ & $\begin{array}{l}\text { Other } \\
\text { reasons }\end{array}$ & $\begin{array}{l}\text { All } \\
\text { of the } \\
\text { above }\end{array}$ \\
\hline $\begin{array}{l}\text { Malaysia } \\
\text { Others }\end{array}$ & $5.1 \%$ & $19.7 \%$ & $10.3 \%$ & $16.2 \%$ & $10.3 \%$ & $15.40 \%$ & $1.7 \%$ & $21.4 \%$ \\
\hline
\end{tabular}

In Table 5, both groups of respondents, $21.4 \%$ (Malaysian respondents) and $27.6 \%$ (other nationalities), agree that 'all of the above' strategies were used to overcome their communication problems in a multicultural group work. Malaysian respondents were more in favour of 'asking for clarification' and having'face-to-face' meetings while the respondents from the other nationalities are in favour of 'checking for understanding' followed by 'asking for clarification' and having face-to-face meeting. Malaysian respondents prefer to communicate using 'Whatsapp' while respondents from the other nationalities do not seem keen to communicate through indirect means of contact. Respondents from the other nationalities prefer to engage with members of the multicultural group directly. 
Table 6

Ways to improve the performance of multicultural group work

\begin{tabular}{|c|c|c|c|c|c|c|c|}
\hline Nationality & $\begin{array}{l}\text { More time } \\
\text { for team- } \\
\text { building }\end{array}$ & $\begin{array}{l}\text { Creating a } \\
\text { flexible } \\
\text { schedule } \\
\text { for the } \\
\text { group } \\
\text { projects }\end{array}$ & $\begin{array}{l}\text { Providing cleares } \\
\text { objectives and } \\
\text { guidelines for thr } \\
\text { projects }\end{array}$ & $\begin{array}{l}\text { More } \\
\text { support } \\
\text { ffrom } \\
\text { the } \\
\text { teachers }\end{array}$ & $\begin{array}{l}\text { More training on } \\
\text { cross cultural } \\
\text { communication } \\
\text { before and during } \\
\text { the group projects }\end{array}$ & $\begin{array}{l}\text { All } \\
\text { of } \\
\text { the } \\
\text { above }\end{array}$ & $\begin{array}{l}\text { Other } \\
\text { reasons }\end{array}$ \\
\hline Malaysia & $i .4 \%$ & $12.0 \%$ & $29.1 \%$ & $8.5 \%$ & $16.2 \%$ & $8.8 \%$ & $0.0 \%$ \\
\hline Others & $10.3 \%$ & $17.4 \%$ & $24.1 \%$ & $10.3 \%$ & $13.8 \%$ & $0.7 \%$ & $3.4 \%$ \\
\hline
\end{tabular}

There are numerous ways to improve the performance of multicultural group work at UCSI University. Both the Malaysian respondents and the respondents from the other nationalities agreed with the statement that suggests 'providing clearer objectives and guidelines for the projects'. Apart from that, respondents from other nationalities selected 'all of the above' which signifies that they want more support from the teachers, to be given more training on cross-cultural communication, more time for team-building as well as creating a flexible schedule for group work.

Table 7

Aspects gained from multicultural team experiences.

\begin{tabular}{llllll}
\hline \multirow{2}{*}{ No. } & \multirow{2}{*}{ Aspects gained from team experiences } & Malaysia & \multicolumn{3}{l}{ Others } \\
\cline { 3 - 6 } & & Yes $(\%)$ & No $(\%)$ & Yes $(\%)$ & No $(\%)$ \\
\hline 1 & Create shared understanding & 42 & 58 & 69 & 31 \\
\hline 2 & Socially integrate & 42 & 58 & 38 & 62 \\
\hline 3 & Develop mutual trust & 40 & 60 & 45 & 59 \\
\hline 4 & Widen cultural knowledge & 60 & 40 & 61 & 39 \\
\hline 5 & Develop interpersonal skills & 52 & 48 & 55 & 45 \\
\hline
\end{tabular}

Table 7 indicates that $69 \%$ of the respondents from the other nationalities believed that one aspect of the experiences in which group members gained from multicultural group work is 'creating a shared understanding'. In addition, many of the respondents from both groups disagreed that members of multicultural group can 'socially integrate' with each other. Since they could not socially integrate it is not surprising that both groups of respondents (approximately 60\%) feel that no mutual trust will be developed from the multicultural group work. It is also revealed in Table 7 that approximately $60 \%$ of the respondents from both groups of respondents agree that working in a multicultural group can widen their cultural knowledge. The responses from both the groups, however, seem to contradict the responses given for the aspects of 'integrating socially' as it is only logical that to widen one's cultural knowledge would require the members of the group to integrate socially with each other. Finally, it was found that more than half of the number of respondents from both groups of respondents agree that working in a multicultural group can help develop interpersonal skills. This is obvious since every member of a group would need to interact with one another to get things done by the group. 
Table 8

Factors that hinder productivity

\begin{tabular}{llllll}
\hline \multirow{2}{*}{ No. } & Factors that hinder communication & \multicolumn{3}{l}{ Malaysia } & \multicolumn{3}{l}{ Others } \\
\cline { 3 - 6 } & & Yes $(\%)$ & No $(\%)$ & Yes $(\%)$ & No $(\%)$ \\
\hline 1 & Communication & 43 & 57 & 78 & 22 \\
\hline 2 & Accent & 40 & 60 & 55 & 45 \\
\hline 3 & Various attitudes & 60 & 40 & 61 & 39 \\
\hline 4 & Work Management & 48 & 52 & 51 & 49 \\
\hline
\end{tabular}

$78 \%$ of the respondents from the other nationalities agree that communication is one of the factors hinders productivity while $57 \%$ of the Malaysians respondents disagree that communication is a problem that obstruct communication in multicultural group work. Although accent is basically the distinctive way in which a particular member of the group pronounces a language strangely, $60 \%$ of the Malaysians respondents do not think that accent hinders productivity while $55 \%$ of the respondents from the other nationalities agree that accent can hinder productivity. It is also only natural that members from differing cultural backgrounds display different attitudes. Their varying attitudes will result in conflicts of interests and ideas. Both groups of respondents (approximately 60\%) agree that the various attitudes of the members of a multicultural group interrupts the flow of the group work. Finally, work management which refers to the abilities of the members in planning, leading, directing, organising, coordinating the activities in the multicultural group effectively and producing successful outcomes, both groups of respondents $48 \%$ (Malaysian's respondents) and 51\% (Others) agree that work management is one of the factors that hinders productivity.

Research Question Two: What are the effects of cross-cultural differences among local and foreign undergraduates towards multicultural group work?

According to Hofstede (2001), 'individualistic' refers to a preference for a loosely-knit social framework in which individuals are expected to take care of only themselves and their immediate families in countries such as the United States or Australia while 'collectivistic' refers to preference for a more closely-knitted social framework by suppressing their identity for the benefit of the group.

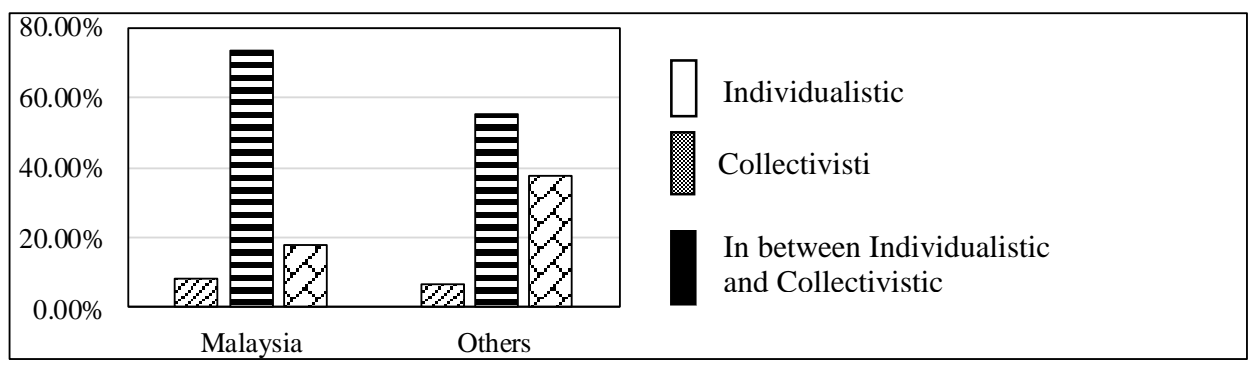

Figure 1

Culture in your home country: Individualistic, collectivistic, and in between individualistic and collectivistic 
Figure 1 clearly shows that more than $70 \%$ of the Malaysians respondents and more than $50 \%$ of the respondents from the other nationalities agree that their country's culture is 'in between individualistic and collectivistic'. Meanwhile, nearly $40 \%$ of the respondents from the other nationalities believe that their country's cultures are 'collectivistic' which is $20 \%$ more compared to the Malaysians respondents. Both groups of respondents (below 10\%) however agree that their countries are 'individualistic'.

'High context culture' refers to the way the words that are said are more important than the words themselves. Therefore, many things are left unsaid, relying on the context of the moment and the culture to impart meaning. In 'low context culture', communication is mostly expressed in words, and little emphasis on non-verbal context.

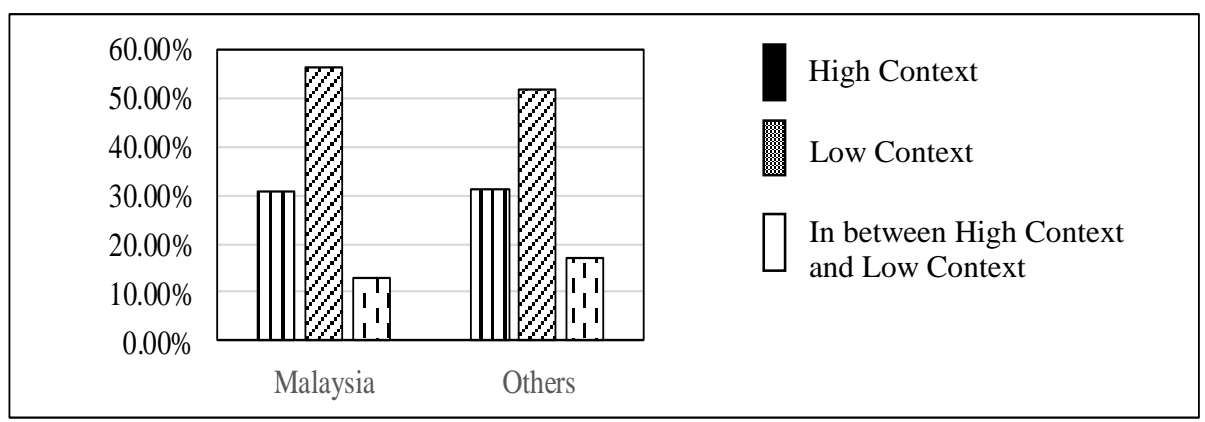

Figure 2

Culture in your home country: High context, low context and in between high context and low context

Figure 2 shows that both groups of respondents believed that the cultures of their countries are 'in between high and low context' (more than 50\%). There is also an equal percentage of respondents from both groups $(30 \%)$ who think that they come from countries with 'high context'. Meanwhile about $18 \%$ of the respondents from other nationalities feel that the come from countries that are 'low context' as opposed to $13 \%$ of respondents from the Malaysian respondents.

\section{Open-ended interview questions:}

Three open-ended interview questions were analysed according to the coding and emergent themes. There were eight interviewees, four Malaysian and four foreign interviewees.

Table 9

Codings of respondents in the formal interview

\begin{tabular}{ll}
\hline Types of Data & Individuals \\
\hline Formal interview & L1-L4- Local undergraduates \\
& I1-I4- Foreign undergraduates \\
\hline
\end{tabular}


The interviewees were randomly selected. L1 is a final year undergraduate undergoing a Biotechnology course. Her mother tongue is Bahasa Malaysia. L2 is a final year undergraduate from the English Language and Communications programme. Her mother tongue is Bahasa Malaysia as well. L3 is a Year 3 undergraduate, and her mother tongue is Chinese. Lastly, L4 is a Mechanic Engineering student. Her mother tongue is Cantonese which is one of the main Chinese Dialects.

The undergraduates from other nationalities studying in UCSI university consist of; I1 who is a final year undergraduate from the English Language and Communications programme. I1 is from Indonesia. I2 is a Year 2 undergraduate from China who is studying Business. I3, is a final year undergraduate who comes from India and is studying Food Science. Lastly, I4 is a Year 1 undergraduate from Indonesia and is currently studying Mechanical Engineering.

Table 10

Ability to cope with cross-cultural differences

\begin{tabular}{|c|c|}
\hline $\begin{array}{l}\text { Willing to } \\
\text { adapt }\end{array}$ & $\begin{array}{l}\text { "I feel like I'm not very open sometimes. But most of the times, I'm willing to adapt" } \\
\text { (L2) } \\
\text { "When the first time I came here, I had a difficulty speaking in English so I solved it with } \\
\text { broken English." (I2) }\end{array}$ \\
\hline Approach & $\begin{array}{l}\text { "I tried to understand the differences between us and ask if whether you understand or } \\
\text { not." (L1) } \\
\text { "They approached me first." (I2) }\end{array}$ \\
\hline $\begin{array}{l}\text { Communicate } \\
\text { using the } \\
\text { same mother } \\
\text { tongue }\end{array}$ & $\begin{array}{l}\text { "There would be some language barriers but people from China is closer to us because } \\
\text { due to the factor that we are Chinese so we are able to communicate in Chinese." (L3) } \\
\text { "There is a vast difference in culture and more differences in language so we } \\
\text { communicate mostly in Chinese." (I2) }\end{array}$ \\
\hline $\begin{array}{l}\text { Depends on } \\
\text { different } \\
\text { culture }\end{array}$ & $\begin{array}{l}\text { "I think my ability to cope depends on the different culture that I am confronting or } \\
\text { working with. I believe that it is more personal than a culture for themselves." (L4) } \\
\text { "I never really felt that there are a lot of different but if there are too many people of the } \\
\text { same ethnicity, they tend to stick together." (I3) }\end{array}$ \\
\hline
\end{tabular}

In a multicultural setting, the multicultural differences are very noticeable, and these generate a lot of discomfort for working in groups due to the challenges and obstacles encountered by members of the group. Despite the problems the L2 and I 2 respondents were willing to adapt to the group. While the L1 student tried to get the message across by using a more personal approach, the I 2 student prefers to let the locals take the first step. The L3 and I 2 respondents resorted to using the same mother tongue, in this case Mandarin. According to I3, people with the same ethnicity tend to stick together while ignoring the other minority of the group. On the other hand, L4 seems to think that the ability to cope within a multicultural work group is a personal issue rather than a cultural difference. 
Table 11

Effects of cross-cultural differences towards multicultural group work

\begin{tabular}{|c|c|}
\hline $\begin{array}{l}\text { Positive effects } \\
\text { (Different ideas) }\end{array}$ & $\begin{array}{l}\text { "I said it would be more positive because the culture may widen our } \\
\text { perception towards our problem." (L3) } \\
\text { "Positive is like you get a lot of different ways or creative ways to approach a } \\
\text { project." (I4) }\end{array}$ \\
\hline $\begin{array}{l}\text { Positive effects } \\
\text { (Understand each } \\
\text { other cultures) }\end{array}$ & $\begin{array}{l}\text { "I think we can make friends with them, exchange different cultures and understand } \\
\text { their cultures." (L2) } \\
\text { "You're looking at things which it's like a new light like different culture and you } \\
\text { are figuring out what are you supposed to be doing." (I4) }\end{array}$ \\
\hline $\begin{array}{l}\text { Negative effects } \\
\text { (Isolate } \\
\text { themselves) }\end{array}$ & $\begin{array}{l}\text { "So in a negative way, some of the international students might be invisible in the } \\
\text { sense that they feel left out. (L4) } \\
\text { "I think it could affect people mentally especially new students, they tend to feel } \\
\text { very isolated especially they left their countries and their home to come all the way } \\
\text { here." (I1) }\end{array}$ \\
\hline $\begin{array}{l}\text { Negative effect } \\
\text { (Too many ideas/ } \\
\text { Clashes of ideas) }\end{array}$ & $\begin{array}{l}\text { "Because when we have so many solutions so we have a difficulty in choosing the } \\
\text { correct one." (L1) } \\
\text { "I've been in group works, multicultural group works where with had a clash of } \\
\text { ideas and it became very intense so it was very hard for us to actually finish the } \\
\text { assignments or the work together." (I2) }\end{array}$ \\
\hline $\begin{array}{l}\text { Negative effect } \\
\text { (Different culture/ } \\
\text { Communication } \\
\text { breakdown) }\end{array}$ & $\begin{array}{l}\text { "The negative could be like there are so many people and share responsibilities and } \\
\text { things are not communicated in a way that they should translate into on the } \\
\text { assignments." (L4) } \\
\text { "I think there are negative things as well and sometimes we cannot understand what } \\
\text { each other are thinking." (I3) }\end{array}$ \\
\hline $\begin{array}{l}\text { Negative effects } \\
\text { (Language barrier) }\end{array}$ & $\begin{array}{l}\text { "But negative I think maybe like due to language barrier sometimes, it happened to } \\
\text { me once uh the person cannot actually talk in English... It takes time but that's the } \\
\text { struggle la." (L1) } \\
\text { "Maybe language barriers. For me, I thought I can't express my opinion correctly to } \\
\text { others. I think they misunderstand of what I said." (I2) }\end{array}$ \\
\hline $\begin{array}{l}\text { Negative effects } \\
\text { (Attitude) }\end{array}$ & $\begin{array}{l}\text { "Because of their attitude problem of so layback and our deadline is very near and } \\
\text { they haven't submitted anything, so we have to do it ourselves." (L3) } \\
\text { "It's normal that we want good grades but others tend to rely on other people." (I2) }\end{array}$ \\
\hline
\end{tabular}

The data obtained from both the local and international undergraduates seemed to have both positive and negative effects of cross-cultural differences towards multicultural group work. This seems to contrast with most of the literature related to multicultural diversity which states that there are many advantages of having a multicultural workgroup. The negative effects were categorised into five main notions. The first being self-isolation. L4 and I1 both stated that foreign undergraduates feel "invisible" or left out as they left their comfortable home and came to live in a foreign land. For notion two, respondents L1 and I2 felt that cultures that are too diverse can cause a lot of confusion when they must come to a consensus. That brings us to notion three; Both the local and foreign respondents (L4 \& I3) felt that there is bound to be an issue when there 
is a communication breakdown. Next, the fourth notion highlights about language barrier. There will result in misunderstandings when one of the communicators does not have the same mastery level as the other. The last notion concerns the person's attitude towards group work. Both foreign respondents (L3 \& I2) felt that some undergraduates tend to be easygoing and more inclined to leave their responsibilities to the other group members.

Table 12

Major barriers encountered in multicultural group work

\begin{tabular}{ll}
\hline Attitude & "I think attitude...Your attitude like you don't really want to try or really don't want to \\
do anything then even though someone is willing to help no work going to. There will \\
be no progress la." (L1) \\
"I think ya, with international students. There is some sort of attitude problem and they \\
are not prone to not wanting to." (I3)
\end{tabular}

Both the Malaysian respondents and the respondents from the other nationalities indicated that creating a successful multicultural group work depends on the attitude of the individuals. Both the local and foreign respondents agreed that language barrier is an on-going issue that both parties face while working together. L3 and I4 clearly stated that the foreign students have the tendency to be quiet and not wanting to speak up during the group work.

\section{DISCUSSION}

The purpose of this study is to find out the undergraduates' attitude and the effect of cross-cultural differences towards multicultural group work among undergraduates at UCSI University. The focus of this study is to look for ways to improve the efficiency and communications among international and local undergraduates in doing group works. Several studies were found to substantiate to the findings of this research. This section discusses the findings and the corresponding data found in the findings and in the literature review. The following are the findings related to the attitude and the effect of cross-cultural differences among the undergraduates.

\section{Local and Foreign Undergraduates' Attitudes Towards Multicultural Group} Work:

There are a lot of responses from the respondents stating the different attitude problems they encountered during multicultural group work which lead to producing unsatisfied 
performance and putting distance on the team members. In line with SimilarityAttraction Paradigm Byrne (1971), the findings show that the international and local students are not attracted to each other as they are not similar in many ways. This affected their attitudes of unwilling to work in a multicultural group. The most common attitude suggested by the respondents are being invisible or getting into 'ghost-mode' especially by the international undergraduates. The foreign students acted this way as they are mainly influenced by their difficulties in adapting to the local culture. Both the international and local students have the perceptions of "not wanted by each other". This is similar to the findings of Volet (1998) in which both groups thought "others are not interested in mixing with them". Other than that, there are different perspectives involved and that caused a lot of disagreements.

Of the many different attitude problems encountered during multicultural group work, the most predominant attitude is, being invisible or getting into 'ghost-mode' especially the respondents from the other nationalities. 'Ghost-mode' typically describes a state of prolonged absence from social life due to tests or term papers (Urban Dictionary, 2006.). This phenomenon is evident in multicultural group work as they were unable to socially integrate with each other resulting in not developing mutual trust.

There were traces of rejection towards this activity of multicultural group work which is supported by Brown's study (2009), which looked at the feeling of isolation that foreign students usually face due to the unfamiliar environment. Both groups also displayed negative feelings even though their numbers may be small which is similar to the findings of Volet and Ang (1998). Matveev and Nelson (2004) quoted that differences in views can account for different attitudes towards team effectiveness, contributing to the person's poor mental health and attitude of neglect towards their studies.

The finding revealed that it was challenging to work in a multicultural group due to a host of problems related to communication with members of the group. Both group of respondents agreed that the factor of 'cross-cultural communication challenges' was the main factor that makes working in a multicultural group work a challenge. Though it was generally agreed that communication hindered productivity, more than $50 \%$ of the Malaysian undergraduates disagreed that communication was a problem that obstructed communication in multicultural group work. This was mainly due to the differing attitudes of the undergraduates which were instilled in them since they are all from different cultural backgrounds. Additionally, both groups of respondents believe that the challenges in multicultural group work are also influenced by the work management although they possessed differing perspectives towards the planning, directing, organising and coordinating the activities in the multicultural group.

According to De Vita (2005), the local students believed that foreign students could have a detrimental effect on their individual mark, compared to working with other local students due to the differences in language skills as they possess different levels of literacy similar to Harrison and Peacock's "passive xenophobia" which is the fear or prejudice from people of other nationalities, cited in Mittelmeier, et al., (2017). Generally, the local students feel they are more capable linguistically and academically. Besides, according to Wegelius (2013), the negative attitude could also be the result of 
stereotyping which is the tendency to ascribe positive or negative characteristics to a person based on a general categorization and perceived similarities.

According to Hung and Mai (2020), to be able to conduct group work alone is insufficient, educators need to be able to design group work into a creative and fruitful activity. Consequently, educators play a vital role as they can include the dimension of multicultural education in the educational environment using multicultural group work (Najeemah, 2005).

\section{Effects of Cross-Culture Differences among Local and Foreign Undergraduates} towards Multicultural Group Work:

Hofstede's Cultural Dimension; "Individualistic versus Collectivistic" quoted by Bantz (1993) whereby different organisational styles and individual responsibility might pose many challenges in building each others' roles in a team was evident amongst the USCI undergraduates. However, some of them are open to the ideas of people from different cultures since some courses they took in UCSI University contain elements of studies that are mainly culture related which encourage different perspectives of understanding when dealing with peers from other cultures. From the local perspective, respondents are generally open to the ideas of people from different cultures. At the same time, even though they seemed more accepting than others, they still have a preference of being the majority to have control and authority over other members in the group. Generally, respondents select Collectivistic more than Individualistic. According to Ochieng (2010), the participants agreed with the same thing when it comes to group work. This can be seen in this study as well, apart from the respondents who describe their culture in their home country as 'in between Individualistic and Collectivistic'. There were more respondents who selected Collectivistic over Individualistic.

According to Kirchmeyer and Cohen (1992), the contributions from the minorities are generally not seen as important. Many local students from UCSI are from the same ethnic group and when one ethnicity is the dominant one, they tend not to socialise or mingle with the minor ethnic groups. The interviews with some of the respondents revealed that this might be the reason why the minority do not contribute to the group work as they feel neglected. Brown's (2009) study reveals that the status of the minority can be a source of vulnerability because of one's culture and race. Furthermore, Quintrell and Westwood (1994) stated that both foreign and local students do not mix with each other except with students from the same background or monoculture educational settings in line with the Similarity Attraction Paradigm by Byrne (1971). There was evidence from the respondents who showed some minor discomforts in working with people from different cultures. However, despite the problem faced, the respondents were willing to adapt and engage with each other using a more personal approach. They also resorted to using the mother tongue (Mandarin). This scenario is in accord with Stahl, Maznevski, Voigt \& Jonsen's study (2010), in which they found that cultural diversity was associated with decreased communication effectiveness.

The respondents strongly believed that cross-cultural differences towards multicultural work group can be resolved through employing strategies such as speaking more clearly, 
asking for clarification, checking understanding, conducting face-to-face meeting, making use of WhatsApp and being patient. They unanimously agreed to carry out strategies such as providing more time for team building, a flexible schedule for group work, provide clear objectives and guidelines, support from teaching staff and orientation programs to enhance cross cultural understanding and development.

\section{CONCLUSION}

The findings of this study focus on the undergraduates' attitudes and the effect of crosscultural difference towards multicultural group work. The most prominent attitude of the respondents is the invisible and getting into 'ghost-mode' during multicultural group work. They do not contribute much to the group work. Most of the respondents felt that ultimately, attitude and language barrier play major roles towards working effectively in multicultural group work. We believe that educators can help the undergraduates to develop the skills of working together in multicultural group work by implementing various strategies to ensure better achievement for undergraduates from different cultures. Potential future research is needed to investigate students' attitudes towards multicultural group work from different aspects as well as provide an evaluation tool to identify individual contributions to multicultural group work and a method of identifying areas for improvement.

This study concludes by suggesting more future research to explore more beneficial and useful strategies for promoting more productive multicultural group work beside exploring barriers that prevent undergraduates from working in cross-cultural groups. The findings of this study might be a useful guide for developing seminars, training programs, and workshops for future and present instructors preparing to teach and work in a cross-cultural setting.

\section{REFERENCES}

Ari, A. \& Stöckli, A. (Eds.) (2021). Switzerland Case as an Example of Success in Multicultural Education. International Journal of Instruction, 14(2).

Bantz, C. R. (1993). Cultural diversity and group cross-cultural team research. Journal of Applied Communication Research, 21(1), 1-20. http://dx.doi.org/10.1080/00909889309365352

Bochner, S., \& Hesketh, B. (2014). Power distance, individualism/collectivism, and jobrelated attitudes in a culturally diverse work group. Journal of Cross-Cultural Psychology, 25(2), 233-257.

Brown, L. (2009). A failure of communication on the cross-cultural campus. Journal of Studies in International Education, 13(4), 439-454.

Byrne, D. (1971). The attraction paradigm. Academic Press.

Creswell, J. W. (2012). Qualitative inquiry \& research design: Choosing among five approaches, (4th ed.). Sage. 
De Vita, G. (2005). Fostering intercultural learning through multicultural group work. In J. Carroll \& J. Ryan (Eds.), Teaching international students: Improving learning for all. Routledge.

Ghost-mode

(2006).

Urban

Dictionary.

https://www.urbandictionary.com/define.php?term=ghost-mode

Hofstede, G. (2001). Culture's consequences, (2nd Ed.). Sage.

Hofstede, G. \& Hofstede, G. J. (2005). Cultures and Organizations: Software of the Mind, (2nd Ed.). McGraw-Hill.

Hung, D. M. \& Mai, L. T. T. (2020). High school teachers' perceptions and implementations of group work in English speaking classes. International Journal of Instruction, 13(2), 445-462.

Iskandarova, S. (2016). The effect of cross-cultural differences on team performance within an educational setting: A mixed methods study. http://commons.lib.jmu.edu/cgi/viewcontent.cgi?article=1080\&context=master201019

Johnson, D. W., Johnson, R. T., \& Smith, K. A. (2014). Cooperative learning: Improving university instruction by basing practice on validated theory. Journal on Excellence in University Teaching, 25(4), 1-26.

Kirchmeyer, C., \& Cohen, A. (1992). Multicultural Groups: Their Performance and Reactions with Constructive Conflict. Group \& Organization Management, 17(2), 153170. https://doi: 10.1177/1059601192172004.

Matveev, A. V., \& Nelson, P. E. (2004). Cross-cultural communication competence and multicultural team performance: Perceptions of American and Russian managers. International Journal of Cross Cultural Management,4(2), 253-270. https://doi: $10.1177 / 1470595804044752$

Mittelmeier, J. \& Rienties, B. \& Tempelaar, D. \& Whitelock, D. (2017). Overcoming cross-cultural group work tensions: mixed student perspectives on the role of social relationships. Open access Springerlink.com

Murphy-Berman, V. \& Berman, J. J. (2002). Cross-cultural differences in perceptions of distributive justice: a comparison of Hong Kong and Indonesia, Journal of CrossCultural Psychology, 33(2), 157-170.

Najeemah Mohd Yusof (2005). Multicultural education practice among teachers in national secondary schools: A case study in Kedah. Jurnal Pendidik dan Pendidikan, 20, 97-111.

Ochieng, E. G., \& Price, A. D. F. (2010). Managing cross-cultural communication in multicultural construction project teams: The case of Kenya and UK. International Journal of Project Management, 28(5), 449-460. 
Quintrell, N. \& Westwood, M. (1994). The influence of a peer-pairing program on international students' first year experience and use of student services. Higher Education Research and Development, 13(1), 49-57.

Reid, R. \& Garson, K. (2016). Rethinking Multicultural Group Work as Intercultural Learning. Journal of Studies in International Education, 21(3), 195-212.

Saaristo, J. (2012). Knowledge Management and Sharing in Multicultural SME Companies Case: Ziliot International Ltd, (October).

Shackleton, V. J., \& Ali, A. H. (1990). Work-Related Values of Managers: A Test of the Hofstede Model. Journal of Cross-Cultural Psychology, 21, 109-118.

Stahl, G. K., Maznevski, M. L., Voigt, A., \& Jonsen, K. (2010). Unravelling the effects of cultural diversity in teams: A meta-analysis of research on multicultural work groups. Journal of International Business Studies, 41(4), 690-709.

Taras, V., \& Rowney, J. (2007). Effects of Cultural Diversity on In-Class Communication and Student Project Team Dynamics: Creating Synergy in the Diverse Classroom. International Studies in Educational Administration (Commonwealth Council for Educational Administration \& Management (CCEAM)), 35(2), 76.

Thomas, D. C. (1999). Cultural diversity and work group effectiveness. Journal of Cross-Cultural Psychology, 30(2), 242-263.

Thomas, D. C., Ravlin, E. C. \& Au, K. (2005). Cultural variation and the psychological contract: The mediating effect of exchange ideology. Paper presented at the Academy of Management Annual Meeting, Honolulu, HI.

Urban Dictionary (2006). Retrieved from: https://www.urbandictionary.com/define.php?term=ghost-mode

Volet, S. E., \& Ang, G. (1998). Culturally mixed groups on international campuses: An opportunity for inter-cultural learning. Higher Education Research and Development, 3l(1), 21-37. https://doi:10.1080/07294360.2012.642838

Wegelius, L. (2013). The Impact of Multiculturalism on Group Work. International Business Management, Turku University of Applied Sciences. Retrieved from: https://www.theseus.fi/bitstream/handle/10024/64576/Wegelius_Laura.pdf?sequence=

Williams, K. Y., \& O'Reilly III, C. A. (1998). Demography and diversity in organizations: A review of 40 years of research. In B. M. Staw \& L. L. Cummings (Eds), Research in organizational behaviour, 20, 77-140. JAI Press.

Wright, S. \& Lander, D. (2003). Collaborative group interactions of students from two ethnic backgrounds'. Higher Education Research and Development, 22, 237-252.

Zedda, M., Bernardelli, S. \& Maran, D. A. (2017). Students' Satisfaction with the Group Work Method and its Performance Evaluation: A survey in an Italian University. International Journal of Instruction, 10(3), 1-14. https://doi.org/10.12973/iji.2017.1031a 